\title{
Effect of Gamma-Vinyl GABA in Friedreich's Ataxia
}

\author{
Y. DE SMET, J.Y. MEAR, G. TELL*, P.H. SCHECHTER*, F. LHERMITTE, Y. AGID
}

\begin{abstract}
SUMMAR Y: Gamma-Vinyl GABA, an irreversible inhibitor of $G A B A$-transaminase, was administered orally in two daily doses of $250 \mathrm{mg}$ to 10 patients with cerebellar ataxia (9 with Friedreich's ataxia, one with olivo-ponto-cerebellar atrophy) for at least one month in an open study. No significant difference occurred in the disability scores of cerebellar symptomatology for the group as a whole, but seven patients showed some improvement in scores with treatment and two patients claimed marked subjective amelioration. Tolerance to Gamma-VinylGABA treatment was excellent. These preliminary results suggest that further studies with well-tolerated agents which enhance CNS GABA-ergic function are warranted in patients with cerebellar ataxia.
\end{abstract}

RÉSUME: Nous avons administré, oralement en deux doses quotidiennes, $\grave{a} 10$ patients souffrant d'ataxie cérébelleuse (dont 9 avec maladie de Friedreich et un avec OPCA) le Gamma-Vinyl-GABA, un inhibiteur irréversible de la GABAtransaminase. Cet essai a duré au moins un mois selon un protocole "ouvert". Pour le groupe entier nous n'avons noté aucune amélioration significative des scores de disabilité cérébelleuse, cependant 7 patients se sont améliorés objectivement et deux subjectivement. La tolérance au traitement fut excellente. Ces études préliminaires suggèrent qu'il serait utile de poursuivre l'investigation des agents modificateurs des fonctions GABA-ergiques chez les patients avec ataxie cérébelleuse.

From Clinique de Neurologie et neuropsychologie Hôpital de la Salpêtrière, Paris, France and * Centre de recherche Merrell International Strasbourgh, France.

Reprint requests for the entire supplement on Friedreich's Ataxia (Phase Three, Part Two) to: Prof. André Barbeau, Clinical Research Institute of Montreal, 110 West Pine Avenue, Montreal, Quebec, Canada, H2W IR7.

\section{INTRODUCTION}

Gamma-aminobutyric acid (GABA) and glutamate concentrations have been reported to be decreased in the cerebellar hemispheres and vermis (Huxtable et al, 1979) of post-mortem brains from patients with Friedreich's ataxia. Although this study involved only two Friedreich's ataxia and four control brains, the data are potentially of clinical interest, because it is theoretically possible to increase GABA levels in the brain. GammaVinyl-GABA (GVG), a specific irreversible inhibitor of GABA-transaminase, produces dose-dependent increases in GABA concentrations in human CSF (Grove et al, 1981). Since whole brain GABA levels and GABA concentrations in experimental animals treated with Gamma-Vinyl-GABA are correlated (Böhlen et al, 1979), it is probable that GABA levels increase in human brain during Gamma-VinylGABA therapy. The present study reports the results of oral administration of GVG to ataxic patients in an attempt to determine whether increasing brain GABA levels improves cerebellar symptomatology.

\section{SUBJECTS AND METHODS}

Ten patients, 9 suffering from classical Friedreich's ataxia (Geoffroy et al, 1976) and one with olivo-pontocerebellar atrophy (Menzel's type), with well-documented and reproducible cerebellar symptomatology were selected for this study (Table 1). There were no nursing or pregnant females among the patients, and none had clinical or laboratory signs of hepatic, renal or cardiovascular deficiency.

Capsules containing GVG $(250 \mathrm{mg} /$ capsule) were administered to the patients who were hospitalized during the first week of treatment and then seen as outpatients until the end of the study (Table 1). No other neurotropic drug was administered, except for lorazepam, $2.5 \mathrm{mg}$ at bedtime, in patient 2 . On the first day of the study, the clinical status of the patients was assessed. The patients then received one gram of GVG, twice daily. Clinical evaluation and biological controls were performed on days 0,7 and on the last day of the study. The functional stage of the disease was evaluated with a rating scale modeled on the one developed by Pourcher and Barbeau (1980). Coordination was estimated from ten items: normal and tandem gait, Romberg sign, right and left finger to nose, right and left heel to knee, right and left adiadocokinesia, postural tremor with extended arms. Each item was rated on a continuous scale from 0 to 3 (absent, slight, moderate or severe disability), giving a maximum score of 30. Each examination was completed by a "tapping" test (tapping laboratory bench with both hands for one minute each) and an evaluation of the patient's voice scored from 0 to 3 (absent, severe abnormality). In addition, each patient was asked to write a standard sentence, and to draw a ladder and Archimede's screw. Patients were also asked to estimate subjectively any improvement as a percentage $(0 \%$, no change; $100 \%$, complete recovery).

\section{RESULTS AND DISCUSSION}

The effects of GVG treatment on cerebellar symptomatology are presented in Figure 1. Whereas only 2 patients( 5 and 10$)$ showed improvement by day 7 (Figure 1), 7 patients were slightly improved after one month or more of treatment. However, no statistically significant improvement was found for the group of patients as a whole. No obvious change was 


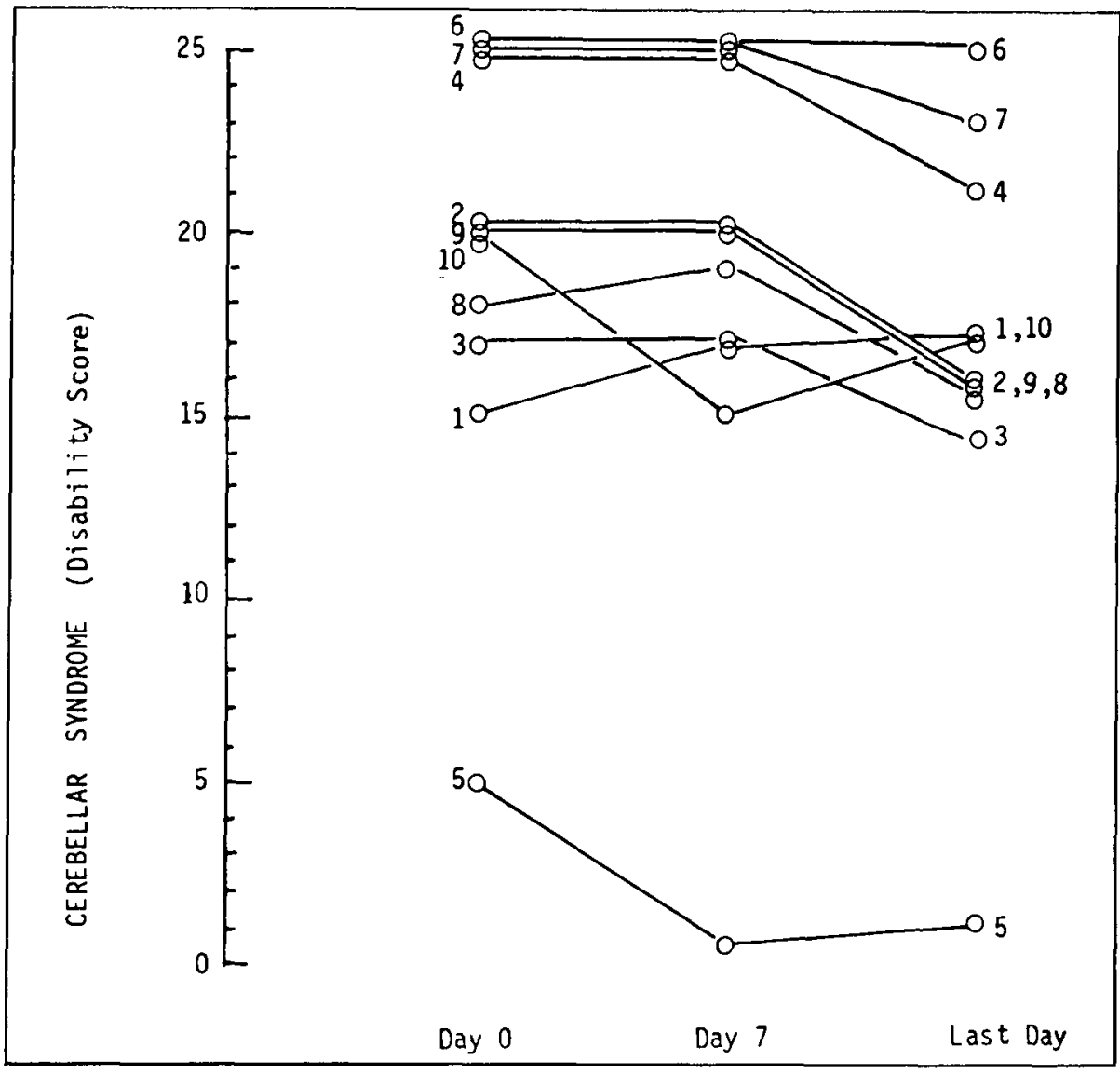

Figure 1 - Disability score of the cerebellar syndrome before (day 0 ) and during day 7 and last day of treatment with gamma-vinyl GABA.

Table 1 : CHARACTERISTICS OF PATIENTS

\begin{tabular}{|c|c|c|c|c|c|}
\hline Patient & $\begin{array}{c}\text { Age } \\
(j 23 \% 5)\end{array}$ & Sex & $\begin{array}{l}\text { Age at onset } \\
\text { (years) }\end{array}$ & Stage" & $\begin{array}{l}\text { Duration of GVG treatment } \\
\text { (days) }\end{array}$ \\
\hline 1 & 23 & $F$ & 15 & III & 49 \\
\hline 2 & 49 & M & 15 & IV & 34 \\
\hline 3 & 45 & M & 5 & IV & 35 \\
\hline 4 & 31 & $\mathrm{~F}$ & 13 & IV & 36 \\
\hline $5^{: \cdots *}$ & 38 & M & 33 & II & 33 \\
\hline 6 & 33 & $\mathbf{F}$ & 13 & IV & 41 \\
\hline 7 & 40 & $\mathbf{F}$ & 16 & $v$ & 41 \\
\hline 8 & 13 & M & 6 & III & 76 \\
\hline 9 & 35 & M & 4 & III & 45 \\
\hline 10 & 46 & $\mathbf{F}$ & 13 & IV & 42 \\
\hline Mean \pm S.E.M. & $35.3 \pm 3.5$ & $\begin{array}{l}5 \mathrm{~F} \\
5 \mathrm{M}\end{array}$ & $\begin{array}{c}13.3 \pm \\
2.6\end{array}$ & $\begin{array}{l}3.6 \pm \\
0.3\end{array}$ & $43 \pm 4$ \\
\hline
\end{tabular}

"See Pourcher and Barbeau, 1980

::: 01 ivo-Ponto-Cerebellar Atrophy (Menzel's Type) observed in the "tapping" scores. Minimal, if any, improvement in voice alteration was noted in patient 4,7 and 10 (Table 2). Only one patient improved in the graphic tests; this patient, who had been unable to hold a pen for years, tried to write and to draw during the last evaluation. Two patients (4 and 7) reported major subjective improvement (higher than $45 \%$ ), one of them was classified in stage IV at the end of the trial rather than V. One additional patient (1) reported 5 . $10 \%$ subjective improvement which contradicted the objective evaluation of coordination disability indicating a slight deterioration of his condition (Figure 1). The other 7 patients reported that they felt neither better nor worse despite apparent improvement of cerebellar symptoms in some.

Tolerance was generally excellent. In only two cases were there complaints of side-effects: patient 1 reported somnolence during the first few days of treatment; patient 5 complained of 1 or 2 episodes of muscle cramps and insomnia. No notable changes were observed in any of the biological parameters measured.

In conclusion, in this open pilot study evaluating the effects of oral GVG on the cerebellar symptomatology in 10 ataxic patients, slight improvements in coordination scores were obtained after at least one month of treatment in 7 out of 10 patients, major subjective improvement was reported by 2 patients. There may be several reasons for the absence of clear-cut effects in the other patients. It is possible that GABA-ergic systems might not, in fact, be affected in patients with ataxia. The decrease in cerebellar GABA levels must be confirmed in other patients with Friedreich's ataxia. It is of interest that no significant differences were observed when CSF concentrations of free and conjugated GABA of ataxic patients were compared to agematched controls with and without neurological disease (Grove et al, in preparation). Alternatively, degeneration of GABA neurons might be so advanced in this disease that inhibition of the transaminase produces little increase in GABA concentrations. This 
latter suggestion is improbable, however, since administration of GVG did result in at least slight improvement in the two most disabled patients in this study, where the theoretical GABA deficiency should have been greatest. These results must be confirmed by a controlled study of chronic GVG treatment.

Table 2

\begin{tabular}{|c|c|c|c|c|c|c|}
\hline \multirow{2}{*}{ Patients } & \multicolumn{3}{|c|}{ "Tapping" test" } & \multicolumn{3}{|c|}{ Volce alteration } \\
\hline & Day 0 & Day $?$ & Last day & Day 0 & Day 7 & Last day \\
\hline 1 & 234 & 234 & 257 & 2 & 2 & 2 \\
\hline 2 & 241 & 238 & 240 & 3 & 3 & 3 \\
\hline 3 & 2.38 & 210 & 215 & 2.5 & 2.5 & 2.5 \\
\hline 4 & 124 & 118 & 146 & 3 & 3 & 3 \\
\hline 5 & 533 & 561 & 568 & 0.5 & 0.5 & 0.5 \\
\hline 6 & 82 & 81 & 77 & 2.5 & 2.5 & 2.5 \\
\hline 7 & 88 & 88 & 97 & 2.5 & 2.5 & 2 \\
\hline 8 & 132 & 176 & 161 & 1.5 & 1.5 & 1.5 \\
\hline 9 & 409 & 413 & 409 & 1.5 & 1.5 & 1.5 \\
\hline 10 & 124 & 123 & 120 & 2 & 2 & 1.5 \\
\hline Mean \pm S.E.M. & $220 \pm 47$ & $224 \pm 49$ & $229 \pm 49$ & $2.1 \pm 0.2$ & $2.1 \pm 0.2$ & $1.9 \pm 0.2$ \\
\hline
\end{tabular}

"Number of counts obtained with both hands for one minute each

: $:$ Scored $0-3$ where $0=$ normal speech, $3=$ severely abnormal

\section{ACKNOWLEDGEMENTS}

We wish to acknowledge Professor A. Barbeau who initiated and continues to encourage research in the field of Friedreich's ataxia. We also thank the patients of the Association Française de l'Ataxie de Friedreich who agreed to participate in this study and the Association Canadienne de l'Ataxie de Friedreich who funded our research program.

\section{REFERENCES}

BOHLEN, P., HUOT, S. and PAL FREYMAN, M.G. (1979). The relationship between GABA concentrations in brain and cerebro-spinal fluid. Brain Research 167, 297-305.

GEOFFROY, G., BARBEAU, A., BRETON, G., LEMIEUX, B., AUBE, M., LEGER, C. and BOUCHARD, J.P. (1976). Clinical description and Roentgenologic Evaluation of Patients with Friedreich's Ataxia. Can. J. Neurol. Sci. 3, 279-286.

GROVE, J., SCHECHTER, P.J., TELL, G., KOCH-WESER, J., SJOERDSMA, A., WARTER, J.M., MARESCAUX, C., RUMBACH, L. (1981). Increased gammaaminobutyric acid (GABA), homocarnosine and $\beta$-alanine in cerebro-spinal fluid of patients treated with gamma-vinyl-GABA. Life Sciences, 28, 2431-2439.

HUXTABLE, R.J., AZARI, J., REISINE, T., JOHNSON, P., YAMAMURA, H.I. and BARBEAU, A. (1979). Regional distribution of Amino acids in Friedreich's Ataxia brains. Can. J. Neurol. Sci. 6, 255-258.

POURCHER, E. and BARBEAU, A. (1980). Field testing of an Ataxia Scoring and Staging System. Can. J. Neurol. Sci. 7, 339-344. 